\title{
Properties of Thermally eVaporated Titanium Dioxide as an Electron-Selective Contact for Silicon Solar Cells
}

\author{
Changhyun Lee ${ }^{1}$, Soohyun Bae ${ }^{1}$, HyunJung Park ${ }^{1}$, Dongjin Choi ${ }^{1}$, Hoyoung Song ${ }^{1}$, \\ Hyunju Lee ${ }^{2}$, Yoshio Ohshita ${ }^{2}$, Donghwan Kim ${ }^{1,3}$, Yoonmook Kang ${ }^{3, *}$ and Hae-Seok Lee ${ }^{3, *}$ \\ 1 Department of Materials Science and Engineering, Korea University, 145 Anam-ro, Seongbuk-gu, \\ Seoul 02841, Korea; changhyuni@korea.ac.kr (C.L.); ramun16@korea.ac.kr (S.B.); jung1029@korea.ac.kr (H.P.); \\ donggenie@korea.ac.kr (D.C.); ghdudlq@korea.ac.kr (H.S.); solar@korea.ac.kr (D.K.) \\ 2 Semiconductor Laboratory, Toyota Technological Institute, 2-12-1 Hisakata, Tempaku, Nagoya 468-8511, \\ Japan; leehyunju@toyota-ti.ac.jp (H.L.); y_ohshita@toyota-ti.ac.jp (Y.O.) \\ 3 KU-KIST Green School, Graduate School of Energy and Environment, Korea University, 145 Anam-ro, \\ Seongbuk-gu, Seoul 02841, Korea \\ * $\quad$ Correspondence: ddang@korea.ac.kr (Y.K.); lhseok@korea.ac.kr (H.-S.L.)
}

Received: 6 January 2020; Accepted: 23 January 2020; Published: 5 February 2020

\begin{abstract}
Recently, titanium oxide has been widely investigated as a carrier-selective contact material for silicon solar cells. Herein, titanium oxide films were fabricated via simple deposition methods involving thermal eVaporation and oxidation. This study focuses on characterizing an electron-selective passivated contact layer with this oxidized method. Subsequently, the $\mathrm{SiO}_{2} / \mathrm{TiO}_{2}$ stack was examined using high-resolution transmission electron microscopy. The phase and chemical composition of the titanium oxide films were analyzed using X-ray diffraction and X-ray photoelectron spectroscopy, respectively. The passivation quality of each layer was confirmed by measuring the carrier lifetime using quasi-steady-state photoconductance, providing an implied open circuit voltage of $644 \mathrm{mV}$. UV-vis spectroscopy and UV photoelectron spectroscopy analyses demonstrated the band alignment and carrier selectivity of the $\mathrm{TiO}_{2}$ layers. Band offsets of $\sim 0.33$ and $\sim 2.6 \mathrm{eV}$ relative to the conduction and valence bands, respectively, were confirmed for titanium oxide and the silicon interface.
\end{abstract}

Keywords: carrier-selective contact cell; electron-selective contact; titanium oxide; band alignment

\section{Introduction}

Most of the commercial solar cell market is based on crystalline silicon wafers. Approximately $90 \%$ of the total silicon produced annually is employed in the photovoltaic (PV) industry. In addition, the market for renewable energy using silicon solar cells is expanding globally, and with the growing development of related industries, PV modules are becoming cheaper. Recently, module prices have dropped to $\$ 0.2$ per watt. The most important challenge in the PV market is to achieve higher-efficiency solar cells with lower cost. In conventional silicon solar cells, a p-n junction should be formed in the solar wafer using doping to separate the photogenerated electron-hole pair. As the dopant concentration increases, the electrons and holes can be separated effectively; however, there are some limitations to the manufacture of high-efficiency solar cells. Auger recombination and parasitic free-carrier absorption caused by high dopant concentrations can reduce the open circuit voltage $\left(V_{o c}\right)$ and short circuit current $\left(J_{s c}\right)$, respectively. It has also been reported that Shockley-Read-Hall (SRH) recombination resulting from dopant complexes reduces the $V_{o c}$ [1-3]. For these reasons, substrate doping-free solar cells have been actively studied, and record efficiency has been achieved with a crystalline cell based on heterojunction technology using intrinsic amorphous silicon (HIT) [4]. Depositing other materials 
onto silicon to collect the photogenerated carriers without substrate doping is termed carrier-selective contact [5]. Materials such as polysilicon [6], metal insulators [7], and transition metal oxides [8-15], as well as amorphous silicon [16], have been deposited on silicon and eValuated as carrier-selective layers. The concept of carrier-selective contact has been studied for a long time, but it has recently regained prominence because of superior passivation properties of the deposited material. Notably, HIT solar cells exhibit high efficiency [16], but it is difficult to optimize the amorphous silicon layer to achieve high passivation quality; in addition, it is difficult to adjust the valence and conduction band offsets at the amorphous silicon/silicon interface [4]. For these reasons, the use of other dopant-free materials as the carrier-selective layer has been studied in the fabrication of high-efficiency cells using simpler methods. Materials such as $\mathrm{TiO}_{2}, \mathrm{LiF}, \mathrm{ZnO}$, and $\mathrm{Ta}_{2} \mathrm{O}_{5}$ have been studied as electron-selective layers, and $\mathrm{MoO}_{\mathrm{x}}, \mathrm{PEDOT}$, and $\mathrm{NiO}$ have been examined as hole-selective layers [9-15].

Figure 1 shows the respective band structures of the homojunction and heterojunction solar cells. Unlike the homojunction cell, in which carriers are separated by substrate doping, the carrier separation is achieved by energy band alignment of the carrier-selective layer and silicon in the heterojunction cell. The carrier selectivity of these layers varies based on the electronic structures of the materials deposited on silicon.
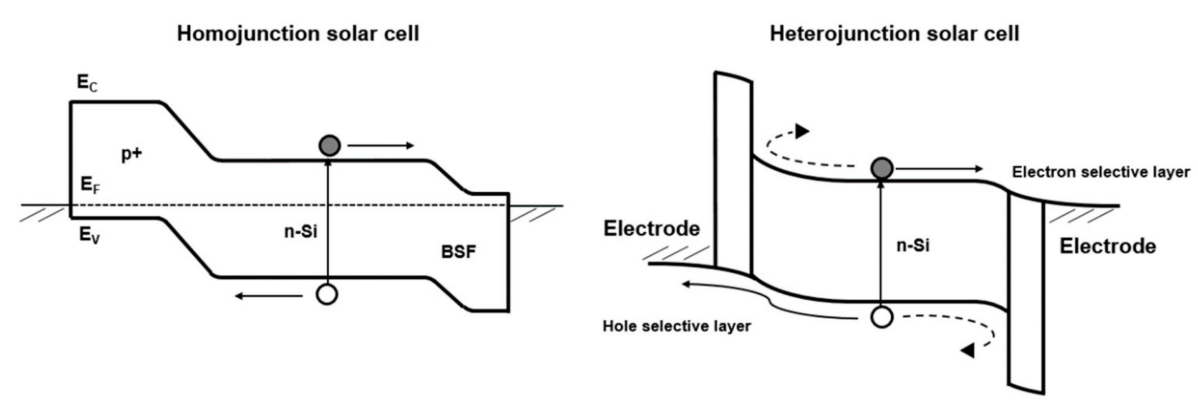

Figure 1. Band diagram of homojunction and heterojunction solar cells.

Titanium oxide is particularly attractive as an electron-selective layer because of the small conduction band offset and a large valence band offset at the interface of $\mathrm{TiO}_{2}$ and n-type Si [17]. Titanium oxide has been studied for a long time as an antireflection film for silicon solar cells and as a hole-blocking material in organic solar cells $[18,19]$. Recently, the possibility of depositing titanium oxide using atomic layer deposition (ALD) as an electron-selective layer on an n-type silicon wafer, instead of using an $\mathrm{n}^{+}$-doped area, has been extensively explored $[9,15,17,20]$. A high-efficiency solar cell (efficiency of over $20 \%$ ) was achieved using a titanium oxide layer deposited by ALD, and various attempts at mass production are underway $[9,21]$.

In this study, we suggest an alternative that does not involve expensive equipment such as ALD for fabricating the titanium oxide layer. In ALD, only the metal oxides with special precursors can be used; however, eVaporation can be applied to various metals. The film is formed by the deposition of titanium metal with a thermal eVaporator, followed by the oxidation using a tube furnace. In a similar approach, electron-beam-processed titanium dioxide was used to form an electron-selective layer [22]; however, the present approach utilizes a thermal eVaporator to avoid electron beam damage. Furthermore, we utilize a thin silicon oxide layer to improve the quality of the layer, and these films are compared with the layers deposited by ALD. After comparing the lifetime data for the titanium oxide layers deposited by ALD with those of the layers deposited by thermal eVaporation, passivation quality analyses are carried out to determine the origin of the difference in the lifetimes. Electrical and optical measurements are performed to examine the band alignment of the film, which acts as an electron-selective contact on the crystalline silicon wafer. The results demonstrate the feasibility of using the low-cost, oxidized titanium layer as a carrier-selective layer. 


\section{Materials and Methods}

\subsection{Preparation of Titanium Dioxide Layers by Two Different Methods}

As shown in Figure 2, the lifetime samples were prepared using n-type Fz monocrystalline Si (100) wafers with a thickness of $\sim 280 \mu \mathrm{m}$ and a resistivity of $\sim 2.5 \Omega \mathrm{cm}$. The wafers were subjected to the conventional standard cleaning process of the Radio Corporation of America using deionized water, $\mathrm{NH}_{4} \mathrm{OH}$, and $\mathrm{H}_{2} \mathrm{O}_{2}$. A thin silicon oxide layer was grown on the wafer surface in $\mathrm{H}_{2} \mathrm{O}_{2}$ solution at $80^{\circ} \mathrm{C}$ over the course of $10 \mathrm{~min}$ [23]. After annealing the silicon oxide, a titanium oxide layer was prepared employing either ALD (Arradiance Inc, MA, USA) using tetrakis (dimethylamino) titanium (TDMAT) with an $\mathrm{H}_{2} \mathrm{O}$ oxidant or thermal eVaporation (CANON ANELVA Co., Kanagawa, Japan) using a titanium metal source. To improve the passivation quality of the titanium oxide deposited by ALD, forming gas annealing (FGA) was performed in a rapid thermal process chamber. In the case of eVaporation, additional annealing in a tube furnace with oxygen gas was required to convert the titanium metal to a titanium oxide layer.

(a)

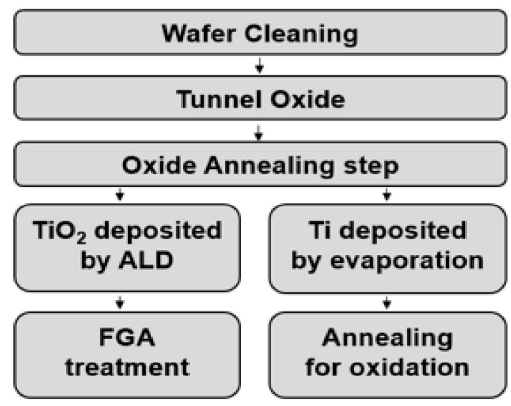

(b)

\begin{tabular}{|c|}
\hline $\mathrm{TiO}_{2}$ deposited by ALD \\
\hline Tunneloxide \\
\hline N-type \\
\hline Tunnel oxide \\
\hline $\mathrm{TiO}_{2}$ deposited by ALD \\
\hline \\
\hline Oxidized Titanium \\
\hline Tunneloxide \\
\hline N-type \\
\hline Tunnel oxide \\
\hline Oxidized Titanium \\
\hline
\end{tabular}

Figure 2. (a) Process flow and (b) schematic structures for the fabrication of symmetrical lifetime samples to eValuate lifetime and implied $V_{o c}$.

\subsection{Sample Measurements}

To eValuate the passivation quality of the $\mathrm{SiO}_{2} / \mathrm{TiO}_{2}$ passivation layer, the WCT-120 equipment (Sinton Instruments, CO, USA) assumed that the recombination of the excess carrier concentration $\Delta n$ occurs according to the following equation [24]:

$$
\frac{\Delta n}{\tau_{e f f}}=\frac{\Delta n}{\tau_{\text {intr }}}+\frac{\Delta n}{\tau_{S R H}}+\frac{J_{0}\left(N_{D}+\Delta n\right) \Delta n}{q W n_{i}^{2}}
$$

where $\tau_{\text {intr }}$ is the lifetime associated with radiative and Auger recombination in the base, $J_{0}$ is the saturation current, $N_{D}$ is the base doping concentration, $n_{i}$ is the intrinsic carrier density, and $\mathrm{W}$ is the wafer thickness. The effective lifetime $\tau_{\text {eff }}$ of the photogenerated carrier shows the quality of the passivated layer. In addition, the implied open-circuit voltage $V_{o c, \text { implied }}$ of the samples under 1 sun illumination (Xenon flash lamp) was determined using a WCT-120 in the quasi-steady-state (QSS) mode according to the following equation proposed by Sinton [25], where kT/q is the thermal voltage, $N_{D}$ is the doping concentration, $\Delta \mathrm{n}$ is the excess carrier concentration related to the effective minority carrier lifetime, and $n_{i}^{2}$ is the intrinsic carrier concentration:

$$
V_{o c, \text { implied }}=\frac{k T}{q} \ln \left(\frac{\left(N_{D}+\Delta n\right) \Delta n}{n_{i}^{2}}\right)
$$

The crystalline structure of titanium oxide layers was examined by grazing incidence X-ray diffraction (GIXRD, X-ray source of $\mathrm{Cu} \mathrm{K} \alpha$, Wavelength of $1.5412 \AA$, X-ray power of $9 \mathrm{~kW}$, Rigaku Co., Tokyo, Japan), and the chemical composition of the layer was analyzed by $\mathrm{X}$-ray photoelectron 
spectroscopy (XPS, X-ray source of $\mathrm{Mg} \mathrm{K} \alpha$, h $v$ of $1253.6 \mathrm{eV}, \mathrm{X}$-ray power of 200W, Kratos, Manchester, $\mathrm{UK})$. The uniformity and thicknesses of the thin silicon oxide and oxidized and $\mathrm{ALD} \mathrm{TiO}_{2}$ layers were confirmed by the LSE Stokes Ellipsometer (Gaertner Scientific Corporation, IL, USA) and cross-section high-resolution transmission electron microscopy (HR-TEM, Thermo Fisher Scientific, MA, USA). The conduction band and valence band alignment between the titanium oxide layer and silicon substrate were analyzed by UV photoelectron spectroscopy (UPS, ULVAC-PHI, Kanagawa, Japan) and UV-vis spectroscopy (Jasco, MD, USA).

\section{Results}

\subsection{Optimizing Titanium Oxide Layer by ALD as Reference}

Symmetrically structured samples with titanium dioxide on the silicon wafer were fabricated with thicknesses varying between 1.5 and $9 \mathrm{~nm}$ by ALD using tunnel silicon oxide $(\sim 1.2 \mathrm{~nm})$. A maximum implied $V_{o c}$ of $690 \mathrm{mV}$ was achieved with a $5 \mathrm{~nm} \mathrm{TiO}$ layer after $\mathrm{FGA}$ at $350{ }^{\circ} \mathrm{C}$ for $3 \mathrm{~min}$. This value is excellent and is comparable with those of high-efficiency titanium oxide electron-selective contact solar cells fabricated by other groups using ALD [26]. Figure 3a shows the implied $V_{o c}$ value and $\tau_{\text {eff }}$ of the thin titanium oxide layers at the injection level of $1 \times 10^{15} \mathrm{~cm}^{-3}$ for changing titanium dioxide thickness.

(a)

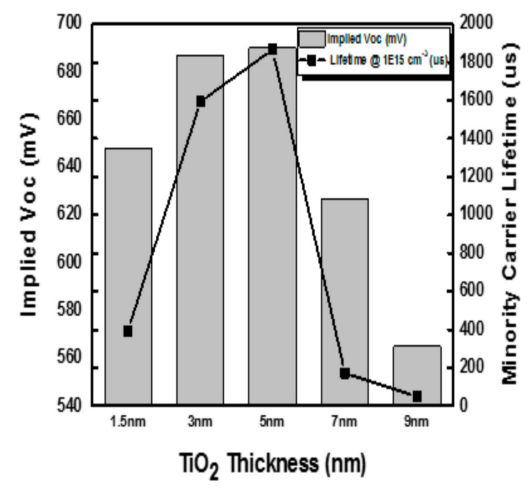

(b)

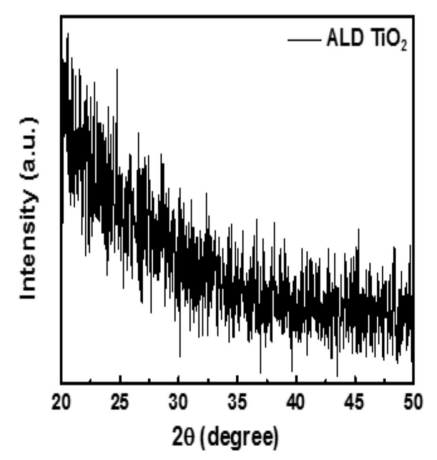

(c)

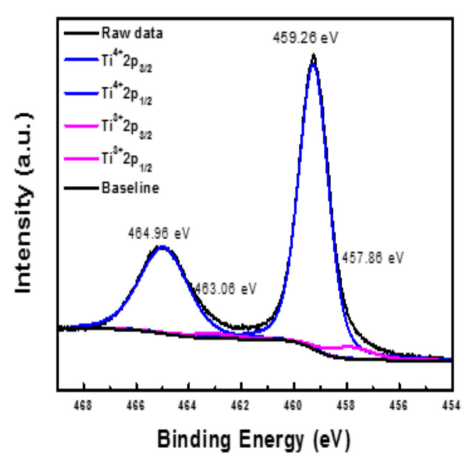

Figure 3. (a) Implied $V_{o c}$ and carrier lifetime data, (b) GIXRD spectra, and (c) Ti $2 p$ XPS spectra of ALD TiO ${ }_{2}$.

The carrier lifetime $\tau_{\text {eff }}$ of the titanium dioxide layer increased as the thickness increased up to $5 \mathrm{~nm}$; however, it decreased as the thickness increased more than $5 \mathrm{~nm}$. As the thickness of the layer increases, the formation of an amorphous titanium oxide layer with high tensile stress induces nucleation of the anatase phase and consequent grain growth. The stress-induced titanium oxide phase is known to degrade the passivation quality of the layer [27]. Usually, the amorphous titanium oxide phase changes to the anatase phase at $\sim 350^{\circ} \mathrm{C}$, which degrades passivation quality. However, in this case, the passivation quality of $\mathrm{SiO}_{2} / \mathrm{TiO}_{2}$ stacks on an n-type silicon wafer was maintained after FGA at $350{ }^{\circ} \mathrm{C}$ for $3 \mathrm{~min}$ because of the silicon oxide interlayer. Figure $3 \mathrm{~b}$ shows GIXRD spectra of $3 \mathrm{~nm}$ titanium oxide deposited by ALD. There was no diffraction peak of anatase or rutile phase found after FGA. Silicon oxide can improve the thermal stability of titanium oxide, and these $\mathrm{SiO}_{2} / \mathrm{TiO}_{2}$ stacks provided a good surface passivation quality after FGA up to $350^{\circ} \mathrm{C}$ [26]. The Ti $2 p$ spectra of Figure $3 \mathrm{c}$ shows the chemical state of the layer. The XPS signals from 459.26 and $464.96 \mathrm{eV}$ each confirmed the presence of the Ti $2 p^{4+} 3 / 2$ and $\mathrm{Ti} 2 p^{4+}{ }_{1 / 2}$ of $\mathrm{TiO}_{2}$ [28].

\subsection{Electronic and Optical Characteristics of Oxidized Titanium Layer}

To fabricate the oxidized titanium layer, a $3 \mathrm{~nm}$ layer of titanium metal was deposited by thermal eVaporation and annealed in a tube furnace under oxygen atmosphere at temperatures of 
250,275 , and $300{ }^{\circ} \mathrm{C}$ for durations of $10-50 \mathrm{~min}$. An effective lifetime of $\sim 100 \mu \mathrm{s}$ at the injection level of $1 \times 10^{15} \mathrm{~cm}^{-3}$ was obtained (Figure 4a) for the sample annealed at $300{ }^{\circ} \mathrm{C}$ for $40 \mathrm{~min}$. The phase of the titanium dioxide layers deposited with this method, subjected to different oxidation conditions, was examined using GIXRD. Figure $4 \mathrm{~b}$ shows the peaks of metallic titanium for the samples treated at $250^{\circ} \mathrm{C}$ and $275^{\circ} \mathrm{C}$. Because these titanium oxide films had a significant metallic character, their passivation properties were poorer than that of the sample annealed at $300{ }^{\circ} \mathrm{C}$. This metallic characteristic degrades the passivation quality by increasing the surface recombination velocity and the saturation current. For the sample that was heat-treated at $300^{\circ} \mathrm{C}$, which exhibited a better passivation quality, the metallic titanium phase was not detected. The inset in Figure $4 \mathrm{~b}$ shows broad $2 \theta$ peak between $20-30^{\circ}$ for the amorphous state of oxidized $3 \mathrm{~nm}$ titanium. There is no anatase or rutile phase of titanium oxide [29]. To examine the chemical oxidation state of the titanium dioxide film that showed the best result (annealed at $300{ }^{\circ} \mathrm{C}$ after deposition of $3 \mathrm{~nm}$ of titanium) at the molecular level, XPS characterization was performed. The Ti $2 p$ spectrum in Figure $4 \mathrm{c}$ shows two peaks, at binding energies of 458.58 and $464.30 \mathrm{eV}$. The position of the Ti $2 p_{3 / 2}$ peak at $458.58 \mathrm{eV}$ was consistent with that of $\mathrm{Ti}^{4+}$ in $\mathrm{TiO}_{2}(\sim 458.6 \mathrm{eV})$. The XPS signals confirmed the presence of titanium dioxide on the sample surface [30].

(a)

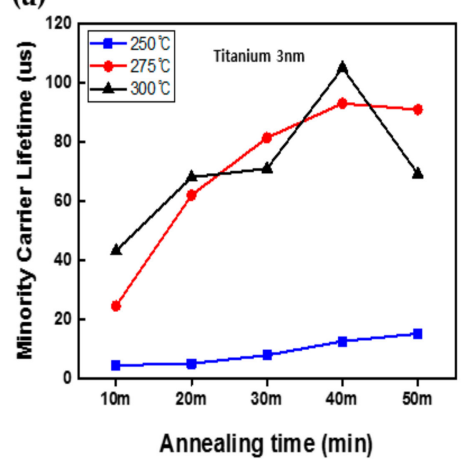

(b)

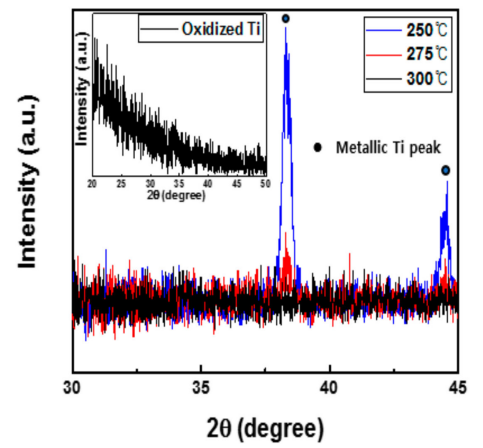

(c)

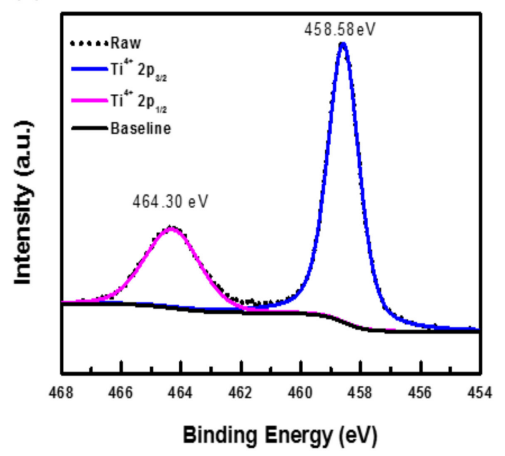

Figure 4. (a) Lifetime according to oxidation temperature and time, (b) GIXRD spectra (inside figure is broader range of GIXRD peak), and (c) Ti $2 p$ XPS spectra of an oxidized titanium layer.

To obtain a high-quality passivation layer with this method, additional experiments were conducted by varying the thickness of the titanium layer using an annealing temperature of $300^{\circ} \mathrm{C}$. As shown in Figure 5a, the carrier lifetime tended to be low after the oxidation if the deposited layer of titanium metal was thick. The longest carrier lifetime at the injection level of $1 \times 10^{15} \mathrm{~cm}^{-3}$ was obtained for the $2 \mathrm{~nm}$ titanium layer annealed at $300{ }^{\circ} \mathrm{C}$ for $10 \mathrm{~min}$ after deposition, and the implied $V_{o c}$ of the layer was $644 \mathrm{mV}$ (Figure 5b). After $20 \mathrm{~min}$ of annealing, the carrier lifetime decreased; however, there was no significant change with further heat treatment up to $50 \mathrm{~min}$. With an oxidation temperature above $250^{\circ} \mathrm{C}$, the extension of annealing has been reported to contribute to breaking the Si-O-Ti bonding at the interface. Thus, the interface passivation quality could degrade when the annealing time is too long [9]. This trend was similar to that of the $1 \mathrm{~nm}$ titanium layer case. Furthermore, for titanium layers with thicknesses more than $5 \mathrm{~nm}$, the lifetime values were low; therefore, it was difficult to confirm meaningful values. During the oxidation process, extra compressive stress was induced at the interface between $\mathrm{TiO}_{\mathrm{x}}$ and the $\mathrm{Si}$ substrate, as the volume of titanium metal deposited on Si substrate expanded [31]. It is expected that the larger residual stress is induced as thicker metal is deposited. The stress could induce the phase transition from the amorphous phase to the anatase phase [32]. In addition, titanium might possibly be left as residual metallic phase without being oxidized, and the stoichiometric composition could be changed during the oxidation when the layer is too thick [33]. The implied $V_{o c}$ results of the oxidized $2 \mathrm{~nm}$ titanium layer showed a similar trend as the lifetime data. 
(a)

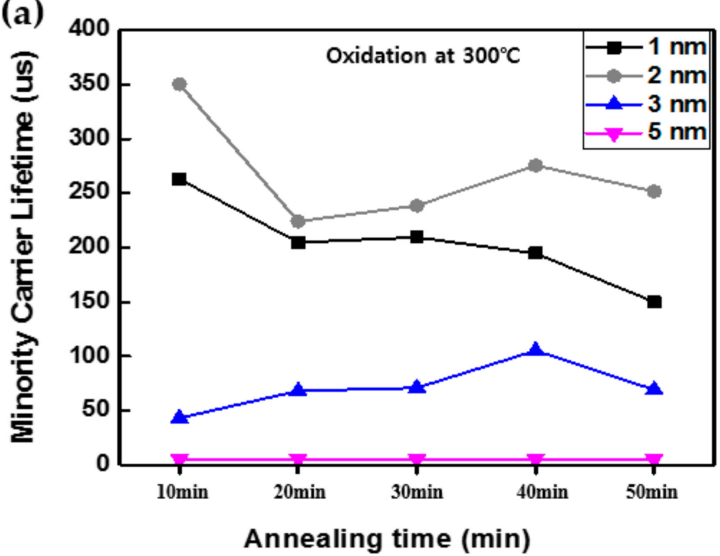

(b)

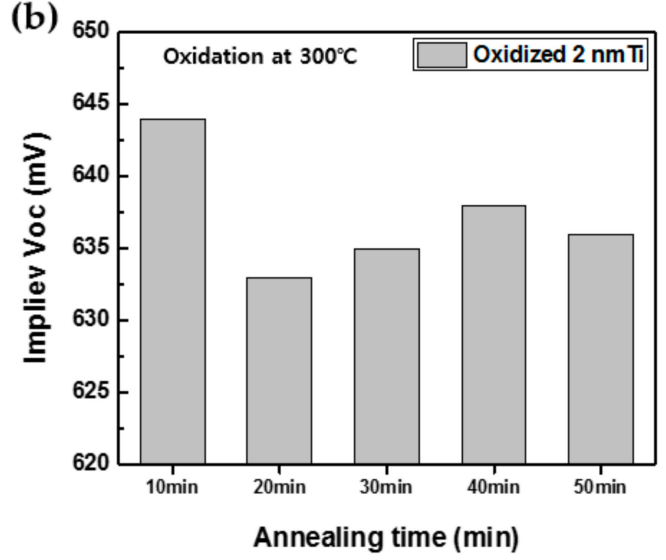

Figure 5. (a) minority carrier lifetime according to thickness of metal layer; (b) implied $V_{o c}$ of oxidized $2 \mathrm{~nm}$ titanium.

After depositing titanium with a thermal eVaporator on the silicon oxide surface, cross-sectional HR-TEM measurements were performed to determine the thickness of the titanium oxide layer. Figure 6 shows the $\mathrm{Si} / \mathrm{SiO}_{2} / \mathrm{TiO}_{2}$ stacks containing titanium oxide deposited by (a) ALD and (b) eVaporation. First, silicon oxide was prepared by the wet chemical method and then annealed at $550{ }^{\circ} \mathrm{C}$ before fabricating the titanium oxide layers. A thickness of $\sim 1.2 \mathrm{~nm}$ was confirmed for the silicon oxide layer by stokes laser ellipsometer with a reflective index $\mathrm{N}$ of 1.45 . In addition, we measured the thickness at five different points on the polished wafer and confirmed that the silicon oxide was uniform.

(a)

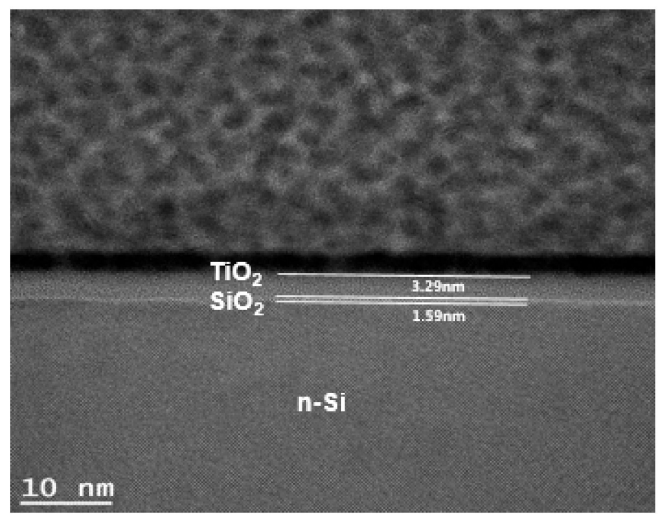

(b)

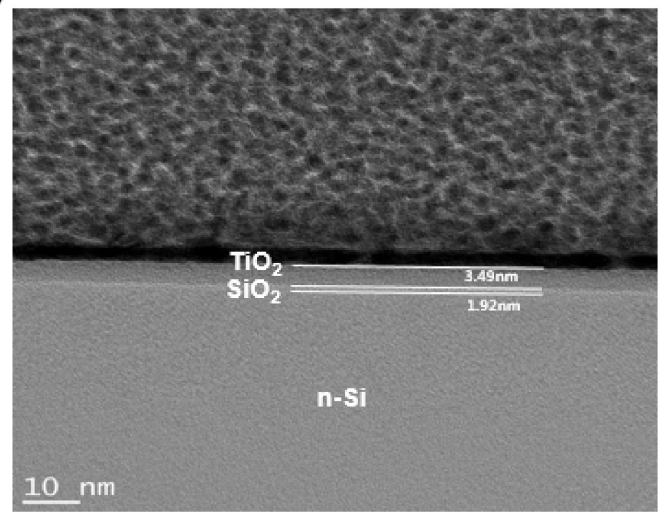

Figure 6. HR-TEM image of $\mathrm{Si} / \mathrm{SiO}_{2} / \mathrm{TiO}_{2}$ stacks prepared by (a) $\mathrm{ALD}$ and (b) thermal evaporation.

The selected ALD samples formed by the deposition of a $3 \mathrm{~nm}$ layer of titanium and subsequent FGA at $350^{\circ} \mathrm{C}$ had an implied $V_{o c}$ of $\sim 685 \mathrm{mV}$. The implied $V_{o c}$ of the sample prepared by the deposition of a $2 \mathrm{~nm}$ layer of titanium metal by thermal eVaporation and subsequent additional oxidation in a tube furnace at $300{ }^{\circ} \mathrm{C}$ was $\sim 644 \mathrm{mV}$. As shown in Figure 6, the silicon oxide layer grew from $\sim 1.2 \mathrm{~nm}$ to (a) $1.59 \mathrm{~nm}$ after FGA and to (b) $1.92 \mathrm{~nm}$ after the oxidation, respectively. In addition, the initial titanium metal layer, $2 \mathrm{~nm}$ thick, grew to $3.49 \mathrm{~nm}$ during the oxidation of the titanium oxide layer.

Titanium oxide is used as an electron-selective layer because of the small band offset (less than $0.5 \mathrm{eV}$ ) in the conduction band when applied to n-type silicon [9]. Because the bandgap and work function depend on the film formation method and composition, UPS and UV-vis spectroscopy measurements were performed to observe the band alignment of titanium oxide formed by the thermal eVaporation method. Figure 7a shows the UPS profile of the oxidized titanium layer. The work function of the layer $\left(\Phi_{\mathrm{TiO} 2}\right)$ was determined from the secondary electron cutoff edge $\left(E_{\text {vacuum }}\right)$ using an equation related to the photon energy $\left(\Phi=h v-\left(E_{\text {vacuum }}-E_{\text {fermi }}\right)\right)$. From the data in Figure 7a, the work function was determined to be $3.93 \mathrm{eV}\left(\Phi_{\mathrm{TiO} 2}=21.2-(17.27-0)\right)$. The valence band maximum $\left(E_{V}\right)$ 
was also determined from Figure $7 \mathrm{a}$ and was found to be $3.27 \mathrm{eV}$ below $E_{f e r m i}$. The above values were similar to those of other groups studying the electronic and optical properties of titanium oxide [30,34]. The work function $(4.6 \mathrm{eV})$ and valence band maximum $(0.68 \mathrm{eV})$ values of the silicon wafers obtained by UPS measurement with a room temperature silicon band gap of $1.12 \mathrm{eV}$ were also similar to those reported in the literature [35]. In addition, the optical gap $(\sim 3.38 \mathrm{eV})$, the band gap of titanium oxide is about 3.0 3.4 eV depending on the crystal structure [36], was determined from the UV-vis absorption spectrum of titanium oxide (10nm of titanium was deposited and oxidized on the glass) using a Tauc plot, as shown in Figure $7 b$ [37]. Based on these data, we were able to confirm the band alignment when titanium oxide was deposited on the silicon substrate through thermal eVaporation, as shown in Figure 7c. The $\Delta E_{V}$ and $\Delta E_{C}$ values for the $n-\mathrm{Si} / \mathrm{TiO}_{2}$ interface were $\sim 2.6$ and $\sim 0.33 \mathrm{eV}$, respectively. From the results of the energy band structure, although further optimization should be needed, the oxidized titanium layer can be an effective candidate of the electron-selective contact material for silicon.
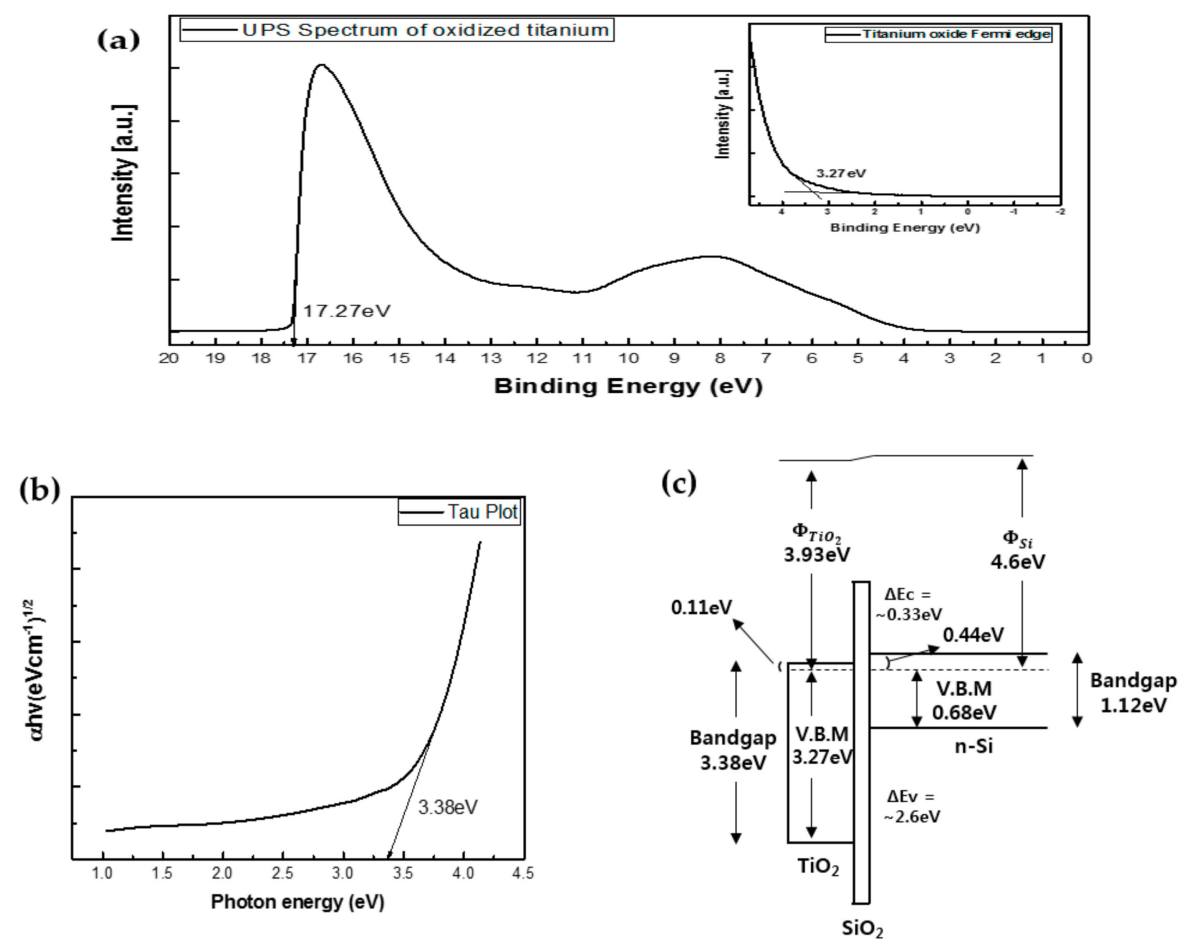

Figure 7. (a) Secondary electron cutoff and Fermi edge data for oxidized titanium, measured by UPS; (b) UV-vis absorption spectra; (c) band diagram of oxidized titanium.

\section{Conclusions}

In this study, electron-selective titanium oxide films were formed via thermal eVaporation and subsequent annealing with oxygen. Using these processes, the characteristics of titanium oxide layers such as passivation quality, composition, and band diagram alignment were investigated. QSSPC (quasi steady state photoconductivity) measurements were performed to determine the lifetime and implied $V_{o c}$ of the samples. To improve the passivation quality of the sample, a silicon oxide $(\sim 1.2 \mathrm{~nm})$ layer was inserted at the interface between titanium oxide and silicon wafer. An implied open circuit voltage of $\sim 644 \mathrm{mV}$ was obtained after the deposition of a $2 \mathrm{~nm}$ titanium layer and oxidation for $10 \mathrm{~min}$ at $300{ }^{\circ} \mathrm{C}$ in a tube furnace for $\mathrm{TiO}_{2} / \mathrm{SiO}_{2} / \mathrm{n}-\mathrm{Si} / \mathrm{SiO}_{2} / \mathrm{TiO}_{2}$ stack. GIXRD measurements showed that the metallic peaks were present eVen after oxidation under $300{ }^{\circ} \mathrm{C}$, indicating poor passivation quality of the oxidized film. However, the XRD and XPS data showed that the titanium film was converted to titanium oxide at temperatures over $300{ }^{\circ} \mathrm{C}$. The passivation quality of the layer varied with the phase of the film and the heat treatment time. If the thickness of the initial deposited metal was thick 
or the oxidation time was not sufficient, the passivation quality was poor. $\mathrm{The}_{\mathrm{SiO}} / \mathrm{TiO}_{2}$ stack showed thermal stability with an implied $V_{o c}$ result of $690 \mathrm{mV}$ for the ALD case after $350^{\circ} \mathrm{C}$, and $3 \mathrm{~min}$ FGA and $644 \mathrm{mV}$ for the oxidized case after annealing at $300{ }^{\circ} \mathrm{C}$. After the oxidation, the silicon oxide layer grew to $\sim 1.92 \mathrm{~nm}$ and the initial $2 \mathrm{~nm}$ titanium layer grew to $\sim 3.49 \mathrm{~nm}$, based on the TEM measurements. In addition, we examined the band alignment of this oxidized layer on silicon wafer using UPS and UV-vis spectroscopy because the electronic properties such as the bandgap and work function of the titanium oxide layer are important as they are dependent on the state of the film. It was found that the band offset was $\sim 0.33 \mathrm{eV}$ for the conduction band, which allows the electron collection to titanium oxide conduction band, and the band offset was $\sim 2.6 \mathrm{eV}$ for the valence band, which blocks the hole collection. Thus, we could confirm that this film was effective as an electron-selective layer for an n-type silicon surface. Furthermore, electrical and optical analyses of this layer showed the feasibility of developing an electron-selective heterocontact silicon solar cell structure with this accessible and low-cost, thermal-evaporated titanium oxide layer.

Author Contributions: Conceptualization, C.L. and H.L.; Methodology, H.L.; Validation, H.-S.L.; Formal Analysis, C.L., D.C., H.S. and Y.K.; Investigation, H.L.; Resources, Y.O. and S.B.; Data Curation, Y.K.; Writing-Original Draft Preparation, C.L.; Writing-Review \& Editing, S.B. and D.K.; Visualization, H.P.; Supervision, Y.O.; Project Administration, D.K.; Funding Acquisition, H.-S.L. All authors have read and agreed to the published version of the manuscript.

Funding: This research was funded by the "Human Resources Program in Energy Technology" and New \& Renewable Energy Core Technology Program of the Korea Institute of Energy Technology eValuation and Planning (KETEP), supported by the ministry of Trade, Industry \& Energy, of the Republic of Korea (No.20154030200760), (No.20163010012430), (No.20188550000450).

Conflicts of Interest: The authors declare no conflict of interest.

\section{References}

1. Baker-Finch, S.C.; Mclntosh, K.R.; Yan, D.; Fong, K.C.; Kho, T.C. Near-infrared free carrier absorption in heavily doped silicon. J. Appl. Phys. 2014, 116, 063106. [CrossRef]

2. Richter, A.; Glunz, S.W.; Werner, F.; Schmidt, J.; Cuevas, A. Improved quantitative description of Auger recombination in crystalline silicon. Phys. Rev. B 2012, 86, 165202. [CrossRef]

3. Schmidt, J.; Cuevas, A. Electronic properties of light-induced recombination centers in boron-doped Czochralski silicon. J. Appl. Phys. 1999, 86, 3175. [CrossRef]

4. Bullock, J.; Hettick, M.; Geissbuhler, J.; Ong, A.J.; Allen, T.; Sutter-Fella, C.M.; Chen, T.; Ota, H.; Schaler, E.W.; Wolf, S.D.; et al. Efficient silicon solar cells with dopant-free asymmetric heterocontacts. Nat. Energy 2016, 1, 15031. [CrossRef]

5. Gao, P.; Yang, Z.; He, J.; Yu, J.; Liu, P.; Zhu, J.; Ge, Z.; Ye, J. Dopant-free and carrier-selective heterocontacts for silicon solar cells: Recent advances and perspectives. Adv. Sci. 2018, 5, 1700547. [CrossRef]

6. Haase, F.; Kiefer, F.; Schafer, S.; Kruse, C.; Krugener, J.; Brendel, R.; Peibst, R. Interdigitated back contacts solar cells with polycrystalline silicon on oxide passivating contacts for both polarities. Jpn. J. Appl. Phys. 2017, 56. [CrossRef]

7. Young, D.L.; Nemeth, W.; Grover, S.; Norman, A.; Lee, B.G.; Stradins, P. Carrier-selective, passivated contacts for high efficiency silicon solar cells based on transparent conducting oxides. Energy Procedia 2014, 55, 733-740. [CrossRef]

8. Xue, M.; Islam, R.; Chen, Y.; Chen, J.; Lu, C.; Pleus, A.M.; Tae, C.; Xu, K.; Kamins, T.I.; Saraswat, K.C.; et al. Carrier-selective interlayer materials for silicon solar cell contacts. J. Appl. Phys. 2018, 123, 143101. [CrossRef]

9. Yang, X.; Bi, Q.; Ali, H.; Davis, K.; Schoenfeld, W.V.; Weber, K. High-performance TiO 2 -based electron-selective contacts for crystalline silicon solar cells. Adv. Mater. 2016, 28, 5891-5897. [CrossRef]

10. Bullock, J.; Zheng, P.; Jeangros, Q.; Tosun, M.; Hettick, M.; Stutter-Fella, C.M.; Wan, Y.; Allen, T.; Yan, D.; Macdonald, D.; et al. Lithium fluoride based electron contacts for high efficiency n-type crystalline silicon solar cells. Adv. Mater. 2016, 20, 1600241. [CrossRef]

11. Khan, F.; Baek, S.; Kim, J.H. Investigation of the surface passivation mechanism through an Ag-doped Al-rich film using a solution process. Nanoscale 2016, 8, 1007-1014. [CrossRef] [PubMed] 
12. Wan, Y.; Karuturi, S.K.; Samundsett, C.; Bullock, J.; Hettick, M.; Yan, D.; Peng, J.; Narangari, P.R.; Mokkapati, S.; Tan, H.H.; et al. Tantalum oxide electron-selective heterocontacts for silicon photovoltaics and photoelectrochemical water reduction. ACS Energy Lett. 2018, 3, 125-131. [CrossRef]

13. Battaglia, C.; Nicolas, S.M.; Wolf, S.D.; Yin, X.; Zheng, M.; Ballif, C.; Javey, A. Silicon heterojunction solar cell with passivated hole selective $\mathrm{MoO}_{x}$ contact. Appl. Phys. Lett. 2014, 104, 113902. [CrossRef]

14. Avasthi, S.; Nagamatsu, K.A.; Jhaveri, J.; McClain, W.E.; Man, G.; Kahn, A.; Schwartz, J.; Wagner, S.; Strum, J.C. Double-heterojunction crystalline silicon solar cell fabricated at $250{ }^{\circ} \mathrm{C}$ with $12.9 \%$ efficiency. IEEE 40 th PVSC 2014, 0949-0952.

15. Imran, H.; Abdolkader, T.M.; Butt, N.Z. Carrier-selective $\mathrm{NiO} / \mathrm{Si}$ and $\mathrm{TiO}_{2} / \mathrm{Si}$ contacts for silicon heterojunction solar cells. IEEE Trans. Electron Devices 2016, 63, 3584-3590. [CrossRef]

16. Yoshikawa, K.; Kawasaki, H.; Yoshida, W.; Irie, T.; Konishi, K.; Nakano, K.; Uto, T.; Adachi, D.; Kanematsu, M.; Uzu, H.; et al. Silicon heterojunction solar cell with interdigitated back contacts for a photoconversion efficiency over 26\%. Nat. Energy 2017, 2, 17032. [CrossRef]

17. Perego, M.; Seguini, G.; Scarel, G.; Fanciulli, M.; Wallrapp, F. Energy band alignment at $\mathrm{TiO}_{2} / \mathrm{Si}_{\text {interface }}$ with various interlayers. J. Appl. Phys. 2008, 103, 043509. [CrossRef]

18. Murozono, M.; Kitamura, S.; Ohmura, T.; Kusao, K.; Umeo, Y. Titanium dioxide antireflective coating for silicon solar cells by spinning technique. Jpn. J. Appl. Phys. 1982, 21, 137. [CrossRef]

19. Van de Lagemaat, J.; Frank, A.J. Effect of the surface-state distribution on electron transport in dye-sensitized $\mathrm{TiO}_{2}$ solar cells: Nonlinear electron-transport kinetics. J. Phys. Chem. B 2000, 104, 4292-4294. [CrossRef]

20. Avasthi, S.; McClain, W.E.; Man, G.; Kahn, A.; Schwartz, J.; Strum, J.C. Hole-blocking titanium-oxide/silicon heterojunction and its application to photovoltaics. Appl. Phys. Lett. 2013, 102, 203901. [CrossRef]

21. Yang, X.; Weber, K.; Hameiri, Z.; Wolf, S.D. Industrially feasible, dopant-free, carrier-selective contacts for high-efficiency silicon solar cells. Prog. Photovolt. 2017, 25, 869-904. [CrossRef]

22. Ling, Z.; He, J.; He, X.; Liao, M.; Liu, P.; Yang, Z.; Ye, J.; Gao, P. Excellent passivation of silicon surfaces by thin films of electron-beam-processed titanium dioxide. IEEE J. Photovolt. 2017, 7, 1551-1555. [CrossRef]

23. Kim, H.; Bae, S.; Ji, K.; Kim, S.M.; Yang, J.W.; Lee, C.H.; Lee, K.D.; Kim, S.; Kang, Y.; Lee, H.; et al. Passivation properties of tunnel oxide layer in passivated contact silicon solar cells. Appl. Surf. Sci. 2017, 409, 140-148. [CrossRef]

24. Sinton, R.; Mcdonald, D. WCT-120 Photoconductance Lifetime Tester and optional Suns-VOC stage User Manual; Sinton Consulting Inc.: Boulder, CO, USA, 2006.

25. Cuevas, A.; Sinton, R.A. Prediction of the open-circuit voltage of solar cells from the steady-state photoconductance. Prog. Photovolt. 1997, 5, 79-90. [CrossRef]

26. Yang, X.; Zheng, P.; Bi, Q.; Weber, K. Silicon heterojunction solar cells with electron selective TiO ${ }_{x}$ contact. Sol. Energy Mater Sol. Cells 2016, 150, 32-38. [CrossRef]

27. Yu, I.; Chang, I.; Cheng, H.; Lin, Y. Surface passivation of c-Si by atomic layer deposition $\mathrm{TiO}_{2}$ thin films deposited at low temperature. IEEE 40th PVSC 2014, 1271-1274.

28. Diebold, U.; Madey, T.E. TiO2 by XPS. Sur. Sci. Spectra 1996, 4, 227. [CrossRef]

29. Zhang, Y.; Ma, X.; Chen, P.; Yang, D. Crystallization behaviors of $\mathrm{TiO}_{2}$ films derived from thermal oxidation of eVaporated and sputtered titanium films. J. Alloys Compd. 2009, 480, 938-941. [CrossRef]

30. He, J.; Ling, Z.; Gao, P.; Ye, J. TiO 2 Films from the low-temperature oxidation of Ti as passivation-contact layers for Si heterojunction solar cells. Sol. SRRL 2017, 1, 1700154. [CrossRef]

31. Taniguchi, S. Stresses Developed during the Oxidation of Metals and Alloys. Trans. Iron Steel Inst. Jpn. 1985, 25, 3-13.

32. Gad, K.M.; Vössing, D.; Richter, A.; Rayner, B.; Reindl, L.M.; Mohney, S.E.; Kasemann, M. Ultrathin Titanium Dioxide Nanolayers by Atomic Layer Deposition for Surface Passivation of Crystalline Silicon. IEEE J. Photovolt. 2016, 6, 649-653. [CrossRef]

33. Ramanavicius, S.; Tereshchenko, A.; Karpicz, R.; Ratautaite, V.; Bubniene, U.; Maneikis, A.; Jagminas, A.; Ramanavicius, A. $\mathrm{TiO}_{2-\mathrm{x}} / \mathrm{TiO}_{2}$-Structure Based 'Self-Heated' Sensor for the Determination of Some Reducing Gases. Sensors 2020, 29, 74. [CrossRef]

34. Man, G.; Schwartz, J.; Sturm, J.C.; Kahn, A. Electronically passivated hole-blocking titanium dioxide/silicon heterojunction for hybrid Si photovoltaics. Adv. Mater. 2016, 3, 1600026.

35. Fulton, C.C.; Lucovsky, G.R.; Nemanich, J. Electronic states at the interface of Ti-Si oxide on Si(100). J. Vacuum Sci. Technol. B 2002, 20, 1726. [CrossRef] 
36. Hannula, M.; Ali-Loytty, H.; Lahtonen, K.; Sarlin, E.; Saari, J.; Valden, M. Improved Stability of Atomic Layer Deposited Amorphous TiO2 Photoelectrode Coatings by Thermally Induced Oxygen Defects. Chem. Mater. 2018, 30, 1199-1208. [CrossRef] [PubMed]

37. O'Leary, S.K.; Lim, P.K. On determining the optical gap associated with an amorphous semiconductor: A generalization of the Tauc model. Solid State Commun. 1997, 107, 17-21. [CrossRef]

(C) 2020 by the authors. Licensee MDPI, Basel, Switzerland. This article is an open access article distributed under the terms and conditions of the Creative Commons Attribution (CC BY) license (http://creativecommons.org/licenses/by/4.0/). 